\title{
Endogenizing technological progress: The MESEMET Model
}

\author{
Peter A.G. van Bergeijk ${ }^{\mathrm{a}, *}$, Gilbert H.A. van Hagen ${ }^{\mathrm{b}}$, \\ Ruud A. de Mooijc, ${ }^{\text {,d }}$, Jarig van Sinderen ${ }^{\mathrm{a}, \mathrm{d}}$ \\ ${ }^{2}$ Economic Policy Directorate, Ministry of Economic Affairs, P.O. Box 20101, 2500 EC The \\ Hague, The Netherlands \\ ${ }^{\mathrm{b}}$ Center for Economic Research, Tilburg University, P.O. Box 9015, 5000 LE Tilberg, The \\ Netherlands \\ ${ }^{\circ}$ Central Planning Bureau (CPB), P.O. Box 80510, 2508 GM The Hague, The Netherlands \\ ${ }^{\mathrm{J}}$ Research Centre for Economic Policy (OCFEB), Erasmus University, P.O. Box 1738, 3000 DR \\ Rotterdam, The Netherlands
}

Accepted July 1996

\begin{abstract}
This paper endogenizes technology and human capital formation in the MESEM model that was developed by van Sinderen (Economic Modelling, 1993, 13, 285-300). Tax allowances for private $R \& D$ expenditures and public expenditures on both education and $R \& D$ are effective instruments to stimulate economic growth. Simulations with respect to market clearing, the importance of supply-side elements and key parameters (such as the magnitude of spillovers and substitution elasticities) reveal that tax allowances for private $R \& D$ are the most robust instrument to increase economic growth through the accumulation of knowledge. Contrary to other studies that find that technology policies typically reduce employment, we find that overall employment rises.
\end{abstract}

JEL classification: E62; H52; J24; O38

Keywords: Human capital; Technology spillovers; Research and development; Technology policy; Macroeconomic regimes; Netherlands

\footnotetext{
0264-9993/97/\$17.00 (C) 1997 Elsevier Science B.V. All rights reserved PIIS0264-9993(97)01041-3
}

${ }^{*}$ Corresponding author. e-mail: p.a.g.vanbergeijk@minez.nl. http://www.minez.nl/aep/eco.htm. 


\section{Introduction}

The background to our analysis is both theoretical and empirical. The endogenous growth theory has shed some new light on the role of governments in fostering economic development. For example, unlike traditional neo-classical theory, the new growth theory shows that both human capital formation, policies to stimulate private $R \& D$, and public investments in infrastructure are important engines of economic growth (Sala-i-Martin, 1990a,b). An important shortcoming of the new growth theory, however, is that progress has been mainly confined to theoretical improvement. Only few attempts have been made to empirically apply the new theories, while the available empirical evidence generally would seem to reject the hypothesis of constant returns to scale, which is a building block for endogenous growth models. This paper builds the insights from the new growth theory into an applied general equilibrium framework in order to investigate the impact of technology policies on macroeconomic variables in an empirically relevant setting. In particular, we endogenize technological progress and knowledge formation in the MESEM model that was developed by van Sinderen $(1990,1993)$. MESEM is an applied general equilibrium model for The Netherlands in which the supply side of the economy is an important determinant of long-term economic performance.

MESEMET eleborates on the MacroEconomic Semi Equilibrium Model (MESEM) by extending it with Endogenous Technology. MESEMET is not an endogenous growth model because it features decreasing returns to scale with respect to the produced factors of production (endogenous growth models require at least constant returns). We follow this modelling strategy because the available empirical evidence does not support the hypothesis of increasing returns to scale (see Benhabib and Jovanovic, 1991; Barro and Sala-i-Martin, 1992; Mankiw et al., 1992; and Maddison, 1995). In the MESEMET model, technology policies affect the supply side of the economy through their impact on the quality of labour (determined by the stock of human capital) and the quality of private physical capital (captured by the stock of public capital and the general stock of technology capital). The model also allows for various spillover effects due to technology policies. Through numerous channels these policies influence macroeconomic variables.

An important contribution of this paper is to illustrate the macroeconomic consequences of technology policies in different institutional settings (or macroeconomic regimes). First, these economic regimes differ with respect to the degree of market clearing on the goods market. Secondly, they differ with respect to the role of supply-side elements (including spillovers). Thirdly, extensive sensitivity analyses explore the nature of technology, i.e. the substitution possibilities between technology, knowledge and other factors of production. Our analysis illustrates that policies that directly influence private incentives to invest in human capital and technology are most likely to stimulate economic growth. Furthermore, we find that both public activities in the field of technology and education and policies that stimulate private $R \& D$ raise the overall level of employment. 
The paper is organized as follows. Section 2 elaborates on the model and explains its main characteristics. The focus is on the new production structure, especially the formation of human capital. Section 3 discusses the parameterization of the model and the methodology concerning the sensitivity analysis. In particular, Section 3 explains the macroeconomic regimes approach that is essential to assess the robustness of our findings. Furthermore, it discusses the parameterization of key parameters in production and relationships that describe the formation of technological and human capital. Section 4 presents simulations for three policy instruments, i.e. public R \& D expenditures, public education expenditures, and tax allowances for private $\mathrm{R} \& \mathrm{D}$ activities. Each of these simulations are carried out in four different economic regimes in order to assess the importance of technical assumptions related to market clearing and supply-side responses of the economy. In addition, Section 4 reports on extensive sensitivity analyses with respect to the parameters that pertain to technology. Section 5 summarizes and discusses the main findings.

\section{Main characteristics of MESEMET}

MESEMET elaborates on the MacroEconomic Semi Equilibrium Model (MESEM) developed by van Sinderen $(1990,1993)$. MESEM attempts to bridge the gap between, on the one hand, applied general equilibrium models with a microeconomic theoretical foundation and, on the other hand, the macroeconometric models typically applied in Dutch policy analysis and policy preparation. MESEM is generally being used at the Ministry of Economic Affairs to analyse the effects of tax and expenditure policies by the government on the supply side of the economy.

The structure of MESEM is founded on microeconomic behaviour. A representative firm maximizes profits under perfect competition. This yields the factor demand relations. The model distinguishes two types of households: entrepreneurs and employees, both of which maximize utility subject to a budget constraint. The utility function of employees has consumption and leisure as arguments. Their budget constraint ensures that labour income is entirely spent on consumption. By contrast, the utility function of entrepreneurs contains current and future consumption. Hence, they choose whether to consume or save. The income of entrepreneurs is determined by the yield on their earlier investments, i.e. capital income. Savings can be invested in two types of financial assets: risky shares or riskless bonds. The government in MESEM has access to labour and capital taxes to finance public expenditures. They include income transfers, civil servants' salaries, public consumption and public investments.

By endogenizing technical progress and human capital, MESEM is enriched and complemented. Indeed, the extended model, MESEMET, offers a tool to explore the macroeconomic effects of technology policies and to analyse the effects of taxation and public spending on human capital and technology. MESEMET covers three important new items compared with MESEM. First, the production block 
contains a wider range of inputs than MESEM by including technology capital and human capital. Secondly, the export equation differs because it explicitly incorporates technology variables. These represent a measure for the quality of domestic products vis-à-vis foreign products. Thirdly, the government in MESEMET has three new instruments: public $R \& D$ expenditures, expenditures on education, and tax-free allowances on private $R \& D$ activities.

\subsection{Production structure}

The extension of the production structure of MESEMET elaborates on the seminal study by den Butter and Wollmer (1992), who endogenized technological progress in a dynamic disequilibrium macreconometric model for The Netherlands. The production structure contains various nested constant elasticity of substitution (CES) functions representing the relationships between the inputs of a representative firm and the corresponding output (see Fig. 1). The production tree in Fig. 1 shows that the production capacity, $Y_{\mathrm{p}}$, is determined by the input of effective capital, $K_{\text {eff }}$, and the effective labour, $L_{\text {eff }}$. These intermediate inputs are not directly observed but are produced by other, observable inputs, such as the capital stock or hours worked. The production function exhibits constant returns to scale at all levels.

The left-hand side of the production tree (Fig. 1) shows that combining labour, $L$ (hours worked), and the stock of human capital, $H C$, yields effective labour, $L_{\text {eff }}$. Human capital is a public good which is given to the individual firm. It represents the average stock of knowledge in society, embodied in all people in the work force.

On the right-hand side of the production tree effective capital, $K_{\text {eff }}$, is produced by combining the public capital stock, $K_{\mathrm{g}}$ (infrastructure and other public services that facilitate private production), and the stock of 'composite capital;', $K T$. The composite input, $K T$, is obtained by combining private physical capital, $K$, and

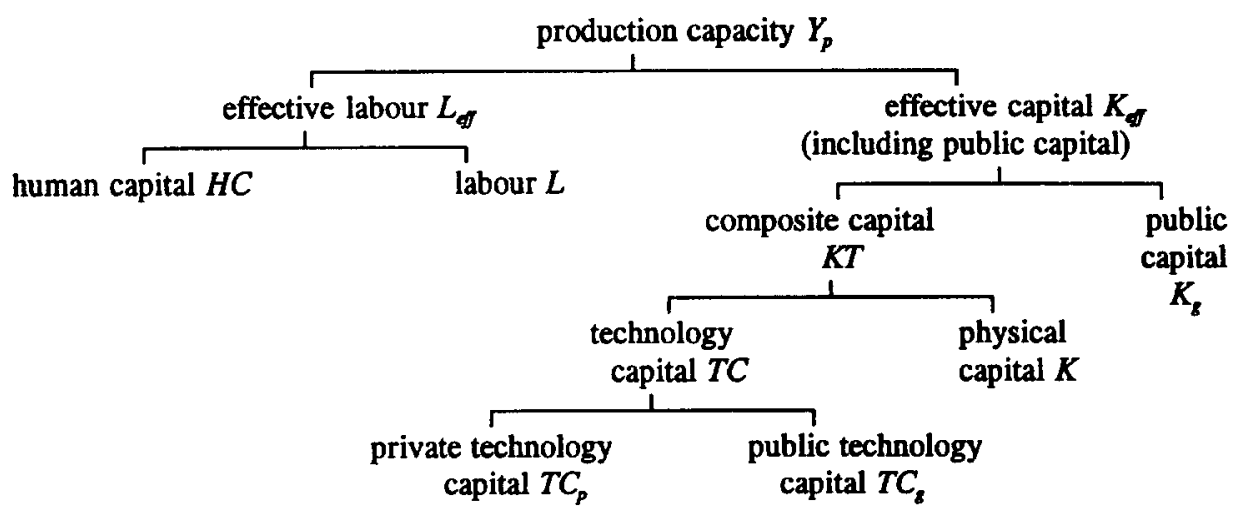

Fig. 1. MESEMET's production structure 
technology capital, TC (all current production technologies embodied in the physical capital used in production). Finally, at the lowest level in the production tree, the stock of technology capital is produced by combining the private technology stock, $T C_{\mathrm{p}}$ (a stock of firm-specific blueprints and production technologies), with the public technology stock, $T C_{\mathrm{g}}$. The stock of public technology capital is the non-rival public stock of knowledge about production technologies. This knowledge is embodied in computers, machines and technological innovations from universities and public research centres, and contributes to private sector production.

Various inputs may be either substitutes or complements. This depends on the relative magnitude of the substitution elasticities between inputs in the production tree. For example, if the substitution elasticity between labour and human capital is relatively small compared with that between effective labour and effective capital, an exogenous increase in the stock of human capital may boost the demand for labour and reduce the demand for physical capital. In other words, human capital in this example is a better substitute for physical capital than for labour so that labour and human capital are complements.

For the individual firm, prices of the various inputs and output, as well as the stocks of human capital, public physical capital and public technology capital, are exogeneously given. The representative firm determines its input choices through profit maximization in a perfectly competitive market. Accordingly, the firm equalizes the marginal product of each input to its producer price. Labour demand, the desired stock of private physical capital and the desired stock of private technology capital are thus determined by both the relative prices of the inputs and the public stocks of human capital, technology capital and productive government capital.

\subsection{Accumulation of human capital and spillovers from $R \& D$ and investments}

Human capital is considered to be a public good. Hence, individual firms or households have no incentive to invest in human capital. Nevertheless, the stock of knowledge can grow as a result of private activities because they cause spillover effects on human capital. In particular, by working with new machines, computers, communication systems, complex capital goods, etc. workers acquire new skills that contribute to their productivity. These new technologies from other domestic industries or from abroad are often embodied in new capital goods. Hence, investment in physical capital, $I_{\mathrm{p}}$, exerts a positive external learning-by-doing effect, thereby raising the stock of human capital (Romer, 1986; and Rebelo, 1991). Learning can also take place by designing. Private $\mathrm{R} \& \mathrm{D}$ activities, $R D_{\mathrm{p}}$, which firms undertake in order to develop more efficient production technologies or new products may, as a side-effect, increase the knowledge of the employees in the firm. In a similar way, the government can also enlarge the stock of human capital by investing in public $\mathrm{R} \& \mathrm{D}, R D_{\mathrm{g}}$, or by increasing expenditures on education, $E_{\mathrm{g}}$. Moreover, as Schultz (1961) pointed out in his seminal article, taxation tends to discriminate against human capital: "Although the stock of such [human] capital has become large and even though it is obvious that human capital, like other 
forms of reproducable capital, depreciates, becomes obsolete, and entails maintenance, our tax laws are all but blind of these matters." In general equilibrium analyses, higher marginal tax rates on labour, $T_{i}$, have been shown to act as a negative incentive to invest in human capital (see, for example, Blinder and Weiss, 1976; Davies and Whalley, 1989; Perroni, 1995; and Trostel, 1993). Hence, we postulate the accumulation of human capital as

$$
\dot{H} c=\alpha_{1} \dot{H} c_{-1}+\alpha_{2} \dot{I}_{\mathrm{p}}+\alpha_{3} R \dot{D}_{p}+\alpha_{4} R \dot{D}_{\mathrm{g}}+\alpha_{5} \dot{E}_{\mathrm{g}}-\alpha_{6} \dot{T}_{i} .
$$

\subsection{Technology capital}

Technology capital accumulates with the amount of $\mathrm{R} \& \mathrm{D}$ efforts, i.e. $R D_{\mathrm{p}}$ and $R D_{\mathrm{g}}$ for private and public technology capital, respectively. Private $\mathrm{R} \& \mathrm{D}$ is assumed to be a continuous variable input. Its price is determined by the level of wage costs, capital costs and a tax allowance for $R \& D$ (which has similar effects as a subsidy):

$$
\dot{T} c p=\beta_{1} \dot{T}_{c p_{-1}}+\beta_{2} R \dot{D}_{\mathrm{p}}
$$

\subsection{International trade in goods and services}

Exports, $B$, depend on world trade, $M_{\mathrm{w}}$, and on the relative export price, $P_{\mathrm{f}}$. In addition, international competitiveness is influenced by relative stocks of technology capital, $R I C$, and human capital, $R H C$. In particular, product or process innovations are often successful in improving the price/quality ratio (Griliches, 1979, p. 97). In macroeconomic models this effect is traditionally modelled by including growth in production capacity or relative investments as an explanatory variable in the export equation (see, for example, Brakman, 1991). The rationale is that when a country has a relatively high-investment ratio or high capacity growth, it will also use modern production methods, which will give it a comparative advantage. In an econometric analysis of the export performance of 41 Dutch sectors in the years 1983-1988, Brouwer and Kleinknecht (1993) find that net exports are significantly influenced by investment per worker. These are interpreted as an indicator for the adoption of technological knowledge embodied in new capital goods. Since we have explicitly modelled the stocks of technology capital and human capital, we allow improvements in these stocks to have an impact on the competitiveness of the Dutch economy (see also den Butter and van Zijp, 1995). Van Hulst and Soete (1989), for example, find that the relative investments in $R \& D$ and relative patenting activity of Dutch manufacturing sectors compared with their foreign competitors is strongly connected to relative export performance:

$$
\dot{B}=\dot{M} w+\gamma_{1}(\dot{P f}-\dot{P})+\gamma_{2} R \dot{I C}+\gamma_{3} R \dot{H} C .
$$


The relative innovative position is measured by the domestic stock of technology capital compared with the stocks of technology capital in foreign countries, $T c_{\mathrm{f}}$, which are given exogenously: $R I C=T C / T c_{\mathrm{f}}$. In addition to innovative comparative advantage, an improvement in the relative stock of human capital, $R H C=$ $H c / H c_{\mathrm{f}}$, exerts a positive effect on exports, where $H c_{\mathrm{f}}$ is the exogenous stock of human capital in foreign countries. The relative stock of domestic knowledge is added to the export equation because not all quality improvements are the result of a specific $\mathrm{R} \& \mathrm{D}$ effort (as measured by $R I C$ ). Learning by doing and, more generally, the level of education of the labour force will also have a positive effect on the range and quality of the products produced.'

\section{Macroeconomic regimes and parameterization}

MESEMET is parameterized for the Dutch economy in 1992, the most recent year for which reliable data are available. Details are given in Van Sinderen (1993) and Ministry of Economic Affairs (1995a,b). Sensitivity analysis is employed on two aspects: the macroeconomic regime and a number of key parameters in the production function.

First, for a good understanding of the impact of technology on the economy it is important to examine this and related issues in different theoretical macroeconomic contexts. Accordingly, we can discover different links between technological and economic variables and test the robustness of quantitative findings in different macroeconomic settings. For example, this paper distinguishes four macroeconomic regimes in which each policy experiment is run several times. The regimes differ with respect to the degree of hysteresis on the product market, i.e. the extent to which markets clear and the presence of supply-side elements and spillovers. Subsection 3.1 discusses the theoretical underpinnings of the regimes approach.

Secondly, the parameterization of certain key parameters, especially those related to technology, has to deal with certain problems. This is either because the evidence is contradictory or because no evidence is available at all. Furthermore, statistical testing is difficult in an applied general equilibrium model. In this paper we seek solutions for these problems in two ways. First, we use a linearized version of the model which allows us to economize on the number of parameters that need to be calibrated. This however, means that only small relative changes in exogenous variables can be studied with the model. Secondly, sensitivity analyses on key parameters are employed to determine the robustness of the policy prescriptions of the model. The parameterization of the key parameters is discussed in Subsection 3.2.

\footnotetext{
${ }^{1}$ Imports $(M)$ depend on the growth of private production $\left(Y_{\mathrm{p}}\right)$ and on the ratio of domestic to foreign prices. Analogous to the specification of the export equation, we could also include the relative stocks of technological and human capital as possible determinants of imports. However, much less is known about the expected signs. Besides, the available empirical evidence is inconclusive. Hence, we assume that the relative stocks of technology and human capital have no effect on imports.
} 


\subsection{Macroeconomic regimes}

The MESEMET framework allows for the investigation of the impact of technology and economic policies in different institutional settings. This investigation is relevant both from a theoretical and from a policy point of view. The actual impact of a policy depends on the macroeconomic regime. For example, is the economy characterized by a Walrasian equilibrium, classical unemployment or Keynesian unemployment? Importantly, The Netherlands is embarking on a course that aims to strengthen the supply side of the economy and to improve the functioning of the market mechanism. Given the uncertainty with respect to the economic structure that will prevail in the medium term it is important to investigate technology policies in different regimes (see van Bergeijk and Haffner, 1996). Four regimes will be discerned depending on the slowness of price adjustment (i.e. hysteresis) and the importance of supply-side elements (Table 1). First, in the original MESEMET version (in the lower left part of Table 1), both product and labour markets clear, while both supply and demand effects are taken into account.

Secondly, we allow for the possibility of separating the demand effects from the supply effects. This is done by running a simulation with the model in which parameters characterizing supply-side elements and spillovers are set equal to zero. Switching off the supply effects, so to say, results in a more or less demand-driven equilibrium model (the upper left part of Table 1).

Thirdly, the institutional setting of market clearing on the product market can be changed by introducing market inertia. This results in the model versions on the right-hand part of Table 1. The importance of market inertia (or hysteresis) in the model is captured by the so-called product market inertia criterion (PMIC) (cf. van Bergeijk et al., 1993). ${ }^{2}$ The version of the model with product market inertia seems

Table 1

The four regimes of MESEMET

\begin{tabular}{lll}
\hline & Market clearing & Market inertia \\
\hline No supply side elements & $\begin{array}{l}\text { Short-term neo- } \\
\text { classical model (SN) }\end{array}$ & $\begin{array}{l}\text { New Keynesian } \\
\text { model (NK) }\end{array}$ \\
$\begin{array}{l}\text { With supply-side elements } \\
\text { (incl. spillovers) }\end{array}$ & MESEMET original & $\begin{array}{l}\text { Empirically } \\
\text { relevant } \\
\text { context (ER) }\end{array}$ \\
\hline
\end{tabular}

\footnotetext{
${ }^{2}$ By definition the PMIC lies between $0 \%$ and $100 \%$. In the case of complete hysteresis (PMIC $=100 \%$ ) neither excess capacity nor excess demand influences the rate of inflation (van Bergeijk and Haffner, 1996). As a result, demand and supply on the goods markets may not equilibrate by means of price adjustment because a central feature of the price mechanism is absent. In contrast, if changes in capacity utilization do not influence price adjustment at all while the level of capacity utilization does, then hysteresis is virtually absent. The PMIC now reaches its $0 \%$ floor. Adjustment is rapid as excess capacity induces price decreases and excess demand generates price increases.
} 
to be more in line with most empirical evidence, at least for The Netherlands for the short and medium terms (Haffner and van Bergeijk, 1994). Product market inertia can be implemented in both the demand oriented equilibrium model (upper part of Table 1) and the model including supply-side elements (lower part).

An important implication of this 'regimes-approach' is that we no longer a priori consider one particular version of the MESEMET model as 'true'. Instead, we explore the effects of various policies in different institutional settings. Thus, we can get a better insight into the robustness of our findings and into the relevance of, on the one hand, supply and demand effects of policies and, on the other hand, inflexibility of markets (or market inertia) on economic and technological processes

\subsection{Key parameters}

The technological parameters have been derived from the literature and are generally based on recent empirical (econometric) studies. Some of these parameters are guesstimates and subjected to sensitivity analysis. Empirical estimates for the Dutch elasticity of substitution between raw labour and human capital by Broer and Jansen (1989) and Hebbink (1991) confirm that (in comparison with aggregate labour and capital), raw labour and human capital are poor substitutes. Accordingly, we set the elasticity of substitution between raw labour and human capital at 0.55 . (This is smaller than the elasticity between effective labour and capital, which is 1.0.) The former elasticity is varied between 0.3 and 0.8 in the sensitivity analysis.

Technology and physical capital are expected to be complementary inputs. The application of newly acquired technological knowledge usually requires some form of investment, i.e. in new machinery and equipment. In a sectoral investigation of the Italian economy, Evangelista (1994) finds that high-tech sectors such as aerospace, telecommunications and office machines are characterized by high levels of both R\&D and investment. Several other sectors, however, show a different pattern, with either high levels of $R \& D$ and low levels of investment (for example, rubber and plastics, textile and general machinery) or high levels of investments and low levels of R \& D (for example, food, chemicals and energy). In general, empirical evidence suggests that, in the long run, physical and R \& D capital are complementary but substitutes for labour, whereas in the short run the evidence is mixed (Shah, 1994). In MESEMET, the substitution elasticity between technology capital and private physical capital is 0.7 . Sensitivity analysis explores the consequences of both lower (0.2) and higher values (1.5).

The substitution possibilities between private and public technology capital, is from a theoretical point of view, similar to the relationship between private and public investments. Public R \& D should be directed at (basic) research activities that, due to market failures, are not sufficiently undertaken in the market sector. A small elasticity would therefore be expected. Indeed, the distributions of public and private R \& D expenditures differ considerably. Whereas public R \& D in The Netherlands is mostly directed at basic and applied research (30\% and $60 \%$, respectively), private $\mathrm{R} \& \mathrm{D}$ outlays are predominantly directed at experimental development (about $60 \%$ ). We set the substitution elasticity between private and 
public technology capital at 0.5 in the base run and vary this elasticity from 0.2 to 1.5 in the sensitivity analysis.

\subsection{Determination of spillovers}

Human capital in our model is accumulated through education and spillovers from private and public $R \& D$, and private investments. The long-run elasticity between human capital and each of these determinants is set equal to its relative expenditure share times its marginal productivity.

Table 2 shows gross expenditures with respect to education, public $R \& D$, private $R \& D$ and private investment (column (1)) and their respective shares in total outlays with respect to the formation of human capital (column (2)). Relatively little, however, is known about the marginal effect of these expenditures on the productivity of individuals (Miller, 1994). ${ }^{3}$ The third column of Table 2 presents our guesstimates for the relative productivity of the four expenditure categories in terms of human capital formation. First, because of their public nature, educational and public R \& D expenditures are expected to have a high payoff in terms of human capital accumulation. Schooling facilities and scientific knowledge are open to many people. Private R\&D and investment probably have smaller spillover effects. In fact, firms and individuals can be expected to keep spillovers to others small, so as to attain a greater proportion of the benefits of the newly acquired knowledge. Since R \& D activities are primarily directed at acquiring additional (technological) knowledge, whereas investments are not, the expected marginal spillover effect on human capital from investment is in turn smaller than that of private $R \& D$. All in all, we assume that additional public expenditures generate three times as much human capital as private $R \& D$, while private $R \& D$ is twice as productive as investment in terms of human capital formation. The final column

Table 2

Determination of long-run elasticities with respect to human capital

\begin{tabular}{llllll}
\hline & $\begin{array}{l}\text { Gross expenditures } \\
\text { (billions of } \\
\text { guilders) } \\
\text { Determinants } \\
\text { of human capital }\end{array}$ & $\begin{array}{l}\text { Share } \\
(\%)\end{array}$ & $\begin{array}{l}\text { Marginal } \\
\text { productivity } \\
\text { index } \\
(3)\end{array}$ & $\begin{array}{l}\text { Product } \\
(4)=(2) *(3)\end{array}$ & $\begin{array}{l}\text { Implied } \\
\text { elasticity } \\
\text { (rounded) } \\
(5)\end{array}$ \\
\hline Education & 15 & 16 & 3 & 48 & 0.45 \\
Public R \& D & 5 & 5.5 & 3 & 17 & 0.15 \\
Private R \& D & 6 & 6.5 & 1 & 7 & 0.05 \\
Private investment & 65.5 & 72 & 0.5 & 36 & 0.35 \\
Totals & 91.5 & 100 & & 108 & 1 \\
\hline
\end{tabular}

${ }^{a}$ Private $R \& D$ is set equal to 1.

\footnotetext{
${ }^{3}$ Our model, however, does not seem to be very sensitive with respect to this question. A doubling of the effects of education has only a minor impact on the simulation results (see van Hagen et al., 1995).
} 
in Table 2 shows the (long-run) elasticities between human capital and education, public $R \& D$, private $R \& D$ and private investment, respectively. These are the results of combining the observable shares and the guesstimates of the marginal productivities.

\subsection{Export equation}

A number of studies have shown the importance of a country's relative technological position for competitiveness (Brouwer and Kleinknecht, 1993; Magnier and Toujas-Bernate, 1994; Fagerberg, 1994; den Butter and van Zijp, 1995). Although these studies do not provide sufficiently clear results for unambiguously establishing the export elasticity with respect to the relative innovative position, they show that this elasticity is positive and significant. With respect to the export elasticity of relative human capital it is possible to deduce a parameter value with a bit more confidence. Reininga (1994) investigates macroeconomic and sectoral wage differentials in The Netherlands in order to estimate the human capital content of exported goods and services. Both at the macroeconomic and at the sectoral levels he finds that the share of human capital in the production of export goods is 0.4 . Hence we put the export elasticity of relative human capital at 0.4. In our simulation we will use a value of 0.6 for the export elasticity with respect to the relative innovative position.

\section{Simulations and sensitivity analysis}

To illustrate the working of the model and the relevance of endogenous technology, this section presents some simulation results with MESEMET. We look at three policy experiments where an increase in expenditures is financed by an increase in public debt in order to balance the government budget ex post. Foreign countries are assumed not to respond to Dutch policies. The simulations are based on:

- a rise in public $\mathrm{R} \& \mathrm{D}$ expenditures of $0.1 \%$ NI (i.e. approximately 470 million guilders in 1992 prices);

- a rise in public expenditures on education of $0.1 \% \mathrm{NI}$;

- a tax-free allowance on private $\mathrm{R} \& \mathrm{D}$ by $0.1 \% \mathrm{NI}$.

The long-run solutions are presented in Table 3. The time-path for most variables is rather smooth. However, for some variables some sort of overshooting in the medium term can occur. For example, a rise in education affects wages, especially in the medium term, but these effects are mitigated in the long run. To obtain insight in the robustness of the findings with MESEMET, we employ a twofold sensitivity analysis. This sensitivity analysis gives us important information about specific mechanisms through which the economy is affected in our model. First, the robustness of the MESEMET simulations is tested with respect to the macroeconomic regime. In particular, we explore the consequences of the three 
Table 3

Long-run economic effects of four policy simulations with MESEMET

\begin{tabular}{lcll}
\hline & $\begin{array}{l}\text { Public R \& D } \\
(0.1 \% \text { NI) }\end{array}$ & $\begin{array}{l}\text { Public } \\
\text { education } \\
(0.1 \% \text { NI })\end{array}$ & $\begin{array}{l}\text { R \& D subsidy } \\
(0.1 \% \text { NI) }\end{array}$ \\
\hline Private employment & 0.0 & -0.1 & 0.0 \\
Overall employment & 0.1 & 0.1 & 0.0 \\
Production & 0.7 & 0.3 & 0.5 \\
Real after-tax wage rate & 0.6 & 0.3 & 0.4 \\
Private consumption & 0.2 & 0.1 & 0.3 \\
Stock of human capital & 1.3 & 1.2 & 0.3 \\
Stock of technology capital & 2.2 & -0.5 & 4.3 \\
Stock of physical capital & -0.5 & -0.8 & 0.1 \\
Imports & 0.7 & 0.1 & 1.0 \\
Exports & 1.6 & 0.7 & 1.5 \\
\hline
\end{tabular}

policy simulations in the four different regimes discussed in Section 3, i.e. with and without supply-side elements and with rigid or with flexible markets (see Table 4, parts (a)-(c)). Secondly, the sensitivity of the simulation results with respect to parameters in the production structure is tested (see Table 5, parts (a)-(c)).

\subsection{Simulations}

\subsubsection{Public $R \& D$}

The first column of Table 3 illustrates the effects of an increase in public expenditures on R \& D by $0.1 \%$ NI in the MESEMET model. This impulse raises the stock of technology capital by $2.2 \%$, and (through its spillover effect on human knowledge) it also boosts the stock of human capital by about $1.3 \%$. The larger stocks of technology capital and human capital expand the production capacity (thereby raising private production by $0.7 \%$ ) and secondly, exports rise by $1.6 \%$ because of the associated improvements in the relative innovative position $(R I C)$ and the relative stock of human capital $(R H C)$ of the Dutch economy compared with foreign competitors. Private consumption rises by about $0.2 \%$ as households experience an increase in disposable income, mainly because of higher wages. Table 3 also reveals that the larger stocks of human and technology capital crowd out private investments in physical capital: the stock of private physical capital falls by about $0.5 \%$. Employment, however, hardly changes when knowledge and technology capital increase. In particular, although private employment remains approximately constant, overall employment rises by about $0.1 \%$ in the long run because of additional labour demand by the government (mainly consisting of additional researchers). The reason for the small effect on employment is that the wage elasticity of labour supply is rather small.

\subsubsection{Public education}

The second column of Table 3 shows that a rise in public expenditures on education in MESEMET by $0.1 \%$ NI boosts the stock of human capital by $1.2 \%$. 
The larger stock of human capital crowds out private R \& D expenditures and private investments in physical capital. Accordingly, the stocks of technology capital and physical capital fall by $0.5 \%$ and $0.8 \%$, respectively. Hence, technology capital and physical capital are net substitutes for human capital. Labour, however, is more complementary to human capital: although private employment slightly falls by $0.1 \%$, overall employment rises by $0.1 \%$ since more people are working in the public education sector.

The fall in the stocks of physical and technology capital exert a negative impact on human capital through their adverse spillover effects. Indeed, the stock of human capital expands even less than in the case of a rise in public R \& D expenditures (compare the first and second column of Table 3). Consequently, the effects on exports, private production and consumption are also smaller than in case of a rise in public $R \& D$. However, these effects are still positive.

\subsubsection{Tax exemptions on private $R \& D$}

If the government reduces the market price of private $R \& D$ expenditures through a specific tax exemption, then the stock of technology capital expands by more than $4 \%$ due to the additional private $R \& D$ (see third column of Table 3 ). The spillover effect of private R \& D on the stock of human capital, however, is rather small: private $R \& D$ contributes to a lesser extent to the general stock of knowledge than either public $\mathrm{R} \& \mathrm{D}$ or education. Hence, this policy simulation shows a minor expansion only of the stock of human capital $(0.3 \%)$. The rise in the stock of technology capital leaves private investment in physical capital and employment almost unchanged, but increases production by $0.5 \%$ and exports by $1.5 \%$. The simulation is most successful in terms of private consumption which rises by $0.3 \%$.

\subsection{Sensitivity analysis}

This subsection discusses the robustness of the MESEMET findings with respect to two aspects of the model. We start with the sensitivity with respect to the macroeconomic regime. This simulation with respect to the regimes helps us to better understand the model, to find out which general assumptions about the (macro) economic system are important and to discover which policies are robust with respect to these general assumptions. Next we discuss the sensitivity with respect to some key parameters in the production function. The sensitivity analyses are very relevant for policy-makers. The potential effectiveness of instruments depends on substitution elasticities that are not accurately known. For example, an increase in public $R \& D$ appears to crowd out private $R \& D$ to some extent and so a policy-maker needs good information on the exact value of the elasticity between physical capital and technology capital. In this sense the simulations may help policy-makers to be aware of their implicit assumptions concerning key parameter values and the prevalent regime and/or the need to have empirical investigations and evaluations relating to the environment in which their instruments are put to work. All simulation results should be interpreted with caution. They do not present exact estimates of the consequences of specific contemplated 
policy measures, but are aimed at obtaining a better understanding of the model. In particular, policy measures affect the economic variables through many different channels. Some of these channels may be positive while others are negative. The parameterization of the model provides some empirical information on the relative importance of these channels. Accordingly, the simulated overall effects of policy measures on the economy depend on both the structure of the model and the specific parameter values chosen.

\subsubsection{The macroeconomic regime}

In Tables 4, parts (a)-(c), we present the simulations of the three policy experiments in four versions of the model. First, the MESEMET results are compared with the regime in which the product market is rigid, rather than flexible. This is referred to as the empirically relevant model (ER model). Indeed, in reality the Dutch economy is characterized by serious market imperfections on the product market (van Bergeijk and Haffner, 1996). The simulation results with the ER model are presented in the second column of parts (a)-(c) of Table 4. Comparing these ER model outcomes with the base version of MESEMET (presented in the first column of Table 4, parts (a)-(c) we find that the effects of various policy measures differ only slightly.

The effects of the various policy measures seem to be rather more promising in the model with flexible markets (MESEMET). For example, an increase of $0.1 \%$ NI in public $R$ \& $D$ raises production in MESEMET by about $0.7 \%$, while in the ER model this is $0.5 \%$. The more favourable economic effect originates mainly from a larger boost in exports in MESEMET.

Overall, we conclude that the MESEMET outcomes are quite robust with respect to the assumptions relating to the flexibility of the goods market, although the effects of policy measures seem to be more promising in a market that is characterized by flexibility, rather than rigidities. Hence, as a side product our analysis supports the view that competition makes technology policy more effective.

The third macroeconomic regime is called the short-term neo-classical model (SN model) as it abstracts from various supply-side elements (including spillovers). The simulations with the SN model are presented in the third column of Table 4, parts (a)-(c). We find that outcomes of the model are highly sensitive to the supply-side elements. In particular, the various policy measures are in general less effective in stimulating economic activity if the supply-side elements are not included (the rise in public expenditure on education in the SN model is the exception). Indeed, tax exemptions on private $R \& D$ hardly exert any effect on the economy in the SN model, while they are very effective if supply-side elements are taken into account. Hence, one important finding is that neglecting these supplyside elements may dramatically underestimate the effectiveness of several policy instruments.

In addition, the sensitivity analysis shows that our findings with MESEMET are rather sensitive with respect to the parameter choices representing these supply-side elements. Although some of these parameters are based on sound empirical evidence (for example, the labour supply elasticity, substitution elasticities in the 
Table 4

MESEMET

ER

SN model

New Keynesian

(a) Effects of a rise in public R \& D expenditures of $0.1 \% \mathrm{NI}$ in four macroeconomic regimes

$\begin{array}{lrrrr}\text { Private employment } & 0.0 & 0.0 & -0.2 & -0.2 \\ \text { Total employment } & 0.1 & 0.1 & 0.0 & 0.0 \\ \text { Production } & 0.7 & 0.5 & 0.2 & 0.1 \\ \text { Real after-tax wage rate } & 0.6 & 0.5 & 0.1 & 0.1 \\ \text { Private consumption } & 0.2 & 0.2 & 0.1 & 0.0 \\ \text { Stock human capital } & 1.3 & 1.3 & 0.0 & 0.0 \\ \text { Stock technology capital } & 2.2 & 2.2 & 2.5 & 2.5 \\ \text { Stock physical capital } & -0.5 & -0.6 & -0.1 & -0.1 \\ \text { Imports } & 0.7 & 0.7 & 0.1 & 0.0 \\ \text { Exports } & 1.6 & 1.3 & 0.3 & 0.1\end{array}$

(b) Effects of a rise in public education of $0.1 \% \mathrm{NI}$ in four macroeconomic regimes

$\begin{array}{lrrrr}\text { Private employment } & -0.1 & -0.1 & -0.1 & -0.1 \\ \text { Total employment } & 0.1 & 0.1 & 0.0 & 0.0 \\ \text { Production } & 0.3 & 0.3 & 0.8 & 0.2 \\ \text { Real after-tax wage rate } & 0.3 & 0.3 & 0.8 & 0.7 \\ \text { Private consumption } & 0.1 & 0.0 & 0.0 & 0.0 \\ \text { Stock human capital } & 1.2 & 1.2 & 3.3 & 3.3 \\ \text { Stock technology capital } & -0.5 & -0.5 & -1.3 & -1.4 \\ \text { Stock physical capital } & -0.8 & -0.9 & -2.4 & -2.6 \\ \text { Imports } & 0.1 & 0.0 & 0.1 & 0.1 \\ \text { Exports } & 0.7 & 0.3 & 1.9 & 0.8\end{array}$

(c) Effects of a rise in R \& D subsidies of $0.1 \% \mathrm{NI}$ in four macroeconomic regimes

$\begin{array}{lllll}\text { Private employment } & 0.0 & 0.0 & 0.0 & 0.0 \\ \text { Total employment } & 0.0 & 0.0 & 0.0 & 0.0 \\ \text { Production } & 0.5 & 0.6 & 0.3 & 0.1 \\ \text { Real after-tax wage rate } & 0.4 & 0.4 & 0.1 & 0.0 \\ \text { Private consumption } & 0.3 & 0.3 & 0.0 & 0.0 \\ \text { Stock human capital } & 0.3 & 0.3 & 0.0 & 0.0 \\ \text { Stock technology capital } & 4.3 & 4.3 & 4.2 & 4.1 \\ \text { Stock physical capital } & 0.1 & 0.1 & -0.3 & -0.3 \\ \text { Imports } & 1.0 & 1.0 & 0.1 & 0.0 \\ \text { Exports } & 1.5 & 1.5 & 0.5 & 0.2\end{array}$

production structure) others are guesstimates because such empirical evidence is presently not available (i.e. technology parameters, the magnitude of spillovers). For instance, the importance of the external effects of $R \& D$ and investment for human capital are very important for the effectiveness of technology policies although it is difficult to determine the numerical values of such spillovers.

Neglecting spillover effects on human capital does not necessarily imply that a policy measure is less effective than with such spillovers. To illustrate, consider part (b) of Table 4 which presents the effects of a rise in public education. By comparing the first and third rows of the table, we can investigate the sensitivity of 
MESEMET with respect to the spillovers in human capital formation. In the SN model, the rise in public education raises the stock of human capital by $3.3 \%$. As discussed above, this crowds out private $\mathrm{R} \& \mathrm{D}$ and private investment. Whereas MESEMET incorporates the adverse spillovers of this crowding-out effect on human capital, they are not taken into account in the SN model. Accordingly, the fall in private $R \& D$ and private investment leaves human capital in the SN model unaffected while it reduces knowledge in MESEMET. Hence, human capital in the SN model rises much more $(3.3 \%)$ than in MESEMET $(1.2 \%)$ while this is associated with a larger drop in the stocks of technology capital $(-0.5 \%$ in MESEMET and $-1.6 \%$ in the SN model) and physical capital $(-0.8 \%$ in MESEMET and $-3.0 \%$ in the SN model). On balance, the SN model suggests a larger increase in private production and real after-tax wages than MESEMET does.

The final columns of Table 4, parts (a)-(c), present the simulation results with the so-called new Keynesian model (NK model). This model does not incorporate supply-side elements and features price rigidities in the product market. Because the NK model shows very similar effects to the SN model, we will not discuss the NK findings in detail.

Overall, we may conclude that the effects of the three policy experiments are not very sensitive to market distortions such as price rigidities. Policies work better in the regime with flexible markets, but they do not work differently. The policies, however, appear to be sensitive with respect to the supply-side elements. This is especially true for production, exports, imports, wages and the stock of human capital. The effects on employment (although small) are also quite robust with respect to the supply-side elements. ${ }^{4}$

\subsubsection{Technology parameters}

In Table 5, parts (a)-(c), we analyse the sensitivity of MESEMET with respect to the key parameters in the production function. In particular, Table 5 presents the simulation results if the Allen elasticities of substitution between human capital and labour $\left(\sigma_{l}\right)$ technology capital and physical capital $\left(\sigma_{k}\right)$, and between private and public technology capital $\left(\sigma_{t}\right)$ are set both lower and higher than their value in the base version of MESEMET.

To start with, the second and third columns of Table 5, part (a), show the sensitivity of the impact of public $R$ \& $D$ with respect to the substitution elasticity between labour and human capital. They reveal that the effect of a rise in public R \& D on the stocks of human capital and technology capital is rather sensitive to this parameter. Whereas the base version of MESEMET yields a rise in technology capital of $2.2 \%$, the sensitivity analysis shows an increase of only $1.6 \%$ if human capital and labour are poorer substitutes. Technology capital rises by $2.6 \%$ if human capital and labour are better substitutes. Intuitively, this elasticity determines the crowding-out effect of additional human capital on private R \& D

\footnotetext{
${ }^{4}$ Note, however, that the assumption that the labour market clears in the long run and the small wage elasticity of labour supply are responsible for this conclusion. Van Hagen et al. (1995) discuss some further sensitivity analyses of labour-market parameters in the case of public expenditures on education.
} 
Table 5

\begin{tabular}{lll} 
& $\sigma_{l}$ & \\
\cline { 2 - 3 } MESEMET & 0.3 & 0.8
\end{tabular}

\begin{tabular}{llll}
$\sigma_{k}$ & & & \\
\hline 0.2 & 1.5 & 0.2 & 1.5
\end{tabular}

(a) Effects of a rise in public R \& D with $0.1 \% \mathrm{NI}$ with different parameterizations of the production structure

$\begin{array}{lrrrrrrr}\text { Employment } & 0.1 & 0.1 & 0.1 & 0.1 & 0.1 & 0.1 & 0.1 \\ \text { Production } & 0.7 & 0.2 & 1.0 & 0.4 & 0.8 & 0.9 & 0.5 \\ \text { Real wage } & 0.6 & 0.7 & 0.5 & 0.4 & 0.7 & 0.8 & 0.4 \\ \text { Technology capital } & 2.2 & 1.6 & 2.6 & 0.5 & 3.5 & 4.2 & 0.6 \\ \text { Human capital } & 1.3 & 0.9 & 1.6 & 1.2 & 1.4 & 1.5 & 1.2 \\ \text { Physical capital } & -0.5 & -1.7 & 0.3 & -0.6 & -0.5 & -0.5 & -0.6\end{array}$

(b) Effects of a rise in public education with $0.1 \% \mathrm{NI}$ with different parameterizations of the production structure

$\begin{array}{lrrrrrrr}\text { Employment } & 0.1 & 0.0 & 0.1 & 0.1 & 0.1 & 0.1 & 0.1 \\ \text { Production } & 0.3 & -0.1 & 0.6 & 0.3 & 0.3 & 0.3 & 0.3 \\ \text { Real wage } & 0.3 & 0.3 & 0.3 & 0.3 & 0.4 & 0.3 & 0.3 \\ \text { Technology capital } & -0.5 & -1.0 & -0.1 & -0.7 & -0.3 & -0.3 & -0.6 \\ \text { Human capital } & 1.2 & 0.8 & 1.5 & 1.2 & 1.2 & 1.2 & 1.2 \\ \text { Physical capital } & -0.8 & -1.9 & -0.1 & -0.8 & -0.8 & -0.8 & -0.8\end{array}$

(c) Effects of a rise in subsidies on private R \& D with $0.1 \%$ NI with different parameterizations of the production structure

\begin{tabular}{llllllll} 
Employment & 0.1 & 0.1 & 0.1 & 0.1 & 0.1 & 0.0 & 0.1 \\
Production & 0.5 & 0.4 & 0.6 & 0.4 & 0.6 & 0.4 & 0.7 \\
Real wage & 0.4 & 0.4 & 0.4 & 0.3 & 0.4 & 0.3 & 0.5 \\
Technology capital & 4.3 & 4.2 & 4.4 & 3.4 & 4.5 & 3.1 & 5.2 \\
Human capital & 0.3 & 0.2 & 0.4 & 0.2 & 0.3 & 0.2 & 0.4 \\
Physical capital & 0.1 & -0.1 & 0.3 & 0.1 & 0.1 & 0.1 & 0.2 \\
\hline
\end{tabular}

Note: In MESEMET we have $\sigma_{l}=0.55, \sigma_{k}=0.7$ and $\sigma_{t}=0.5$.

expenditures. If $\sigma_{l}$ is smaller, then capital is a better substitute for human capital than labour. Hence, the stock of capital (including technology capital) falls more, thereby also adversely affecting private production. However, if $\sigma_{l}$ becomes larger compared with capital, then labour is much better substitute for human capital. Hence, whereas private employment falls (although slightly and not visibly in our rounded figures), the stock of technology capital is boosted more substantially, thereby also raising production. The effects on production lie in the range between $0.2 \%$ and $1.0 \%$ for different parameter values. Although this range is rather broad, the effects on production appear to be typically positive.

The second important elasticity is that between physical capital and technology capital $\left(\sigma_{k}\right)$. A rise in public $\mathbf{R} \& \mathrm{D}$ is much more effective in raising the stock of technology capital if this elasticity is large. If producers find its easier to substitute physical capital, rather than private technology capital, for public technology capital, public R \& D will exert a much smaller crowding-out effect on private $R \& D$. Consequently, the drop in private $R \& D$ will be much smaller. A large value of $\sigma_{k}$ thus implies that technology capital rises more, thereby also implying a larger increase in production. In particular, whereas MESEMET finds an increase 
in production of $0.7 \%$, the range of different values for $\sigma_{k}$ lies between $0.4 \%$ and $0.8 \%$. The elasticity between private and public technology capital also has important consequences for the simulation results (see the sixth and seventh column of Table 5, parts (a)-(c). Indeed, if private and public technology capital are poor substitutes (i.e. $\sigma_{t}$ is small), a rise in public $\mathrm{R} \& \mathrm{D}$ will not crowd out private $\mathrm{R} \& \mathrm{D}$. Hence, in that case the stock of technology capital will expand to a larger extent, thereby also imposing a larger increase in production. The range for production is between $0.5 \%$ and $0.9 \%$.

From Table 5, part (b), we see that the effects of a rise in education are rather robust with respect to variations in $\sigma_{k}$ and $\sigma_{t}$. However, the effects of public education are very sensitive with respect to the substitution elasticity between labour and human capital. Indeed, if labour and human capital are very poor substitutes (i.e. $\sigma_{l}=0.3$ ), output falls by $0.1 \%$, while in MESEMET it rises by about $0.3 \%$. This is because the rise in human capital exerts a more substantial crowding-out effect on private $\mathrm{R} \& \mathrm{D}$ and investment in physical capital since these inputs are much better substitutes for human capital than labour is. The reductions in technology capital and physical capital are responsible for the fall in output. However, if labour is a better substitute for human capital than it is in MESEMET $\left(\sigma_{l}=0.8\right)$, then output rises by $0.6 \%$. Indeed, the crowding-out effect on investment and $\mathrm{R} \& \mathrm{D}$ is reduced to $0.1 \%$. The simulation results of a rise in tax exemptions on private $R \& D$ are rather robust with respect to the substitution elasticity between labour and human capital (Table 5, part (c)). Changes in the other two elasticities cause larger changes in the results. Nevertheless, the consequences of tax exemptions on private $R \& D$ turn out to be less sensitive with respect to the substitution elasticities than publicly provided $R \& D$ and education. Indeed, whereas these latter have the risk of crowding out private investments in capital or R \& D, tax-free allowances on private R \& D typically stimulate these private investments. Hence, there is less risk of a crowding-out effect. The stock of technology capital is sensitive to the substitution elasticities between technology and physical capital and between private and public technology capital. The easier producers find it to substitute private technology capital for other inputs (i.e. the larger $\sigma_{k}$ and $\sigma_{t}$ ), the more effective tax-free allowances on $\mathrm{R} \& \mathrm{D}$ are in stimulating the stock of technology capital and the production capacity.

An important finding from Table 5 is that the effect of technology policies on private employment is rather insensitive to changes in production function parameters. Indeed, the effects on total employment is positive but very small in most simulations. Other variables in MESEMET are sometimes rather sensitive with respect to the values of key parameters in the production structure. However, the signs of the simulations with MESEMET are robust. In particular, technology policy, either through public $R \& D$ activities or by exempting part of private $R$ \& $D$ from taxation, is a very attractive policy option for increasing economic growth in all simulations. Public education, although less effective, may also be favourable for economic growth. 


\section{Discussion}

This study endogenizes technological progress and human capital formation in an applied general equilibrium model in an attempt to analyse the (in)direct relationships between economic policy and technology in The Netherlands. An important caveat is that the focus of the analysis for practical matters is on national policies and ignores potential public and private activity in other countries which, in any case, are hard to predict. However, if foreign $R \& D$ and human capital increase, this may constitute an important argument for active government involvement in public and domestic R \& D.

Table 6 summarizes the three policy simulations, reporting the ranges of our findings in the twofold sensitivity analysis. The first message that the tables conveys is one of substantial indeterminacy. Indeed, our assessment of these exercises is a modest one. Owing to both data deficiencies and the fact that no full agreement has yet emerged among economists about either the potential relevance or the actual empirical impact of (endogenous) technological progress, our findings by definition suffer from many uncertainties. This is shown by the rather substantial differences between the lower and upper bounds of the reported estimates.

The second conclusion from our analysis is that technology policy that directly affects private behaviour is less sensitive to the parameters in the model. Since public activities might crowd out private investments, stimulating private investments in $\mathrm{R} \& \mathrm{D}$ enhances economic performance with a larger probability than public activities

Thus, endogenizing technological progress in an empirically relevant context turns out to be important. This is illustrated by the fact that the extensive

Table 6

Summary table of the ranges of the impact of four policy instruments (policy shocks of $0.1 \% \mathrm{NI}$, minimum and maximum long-run percentage deviations from the base run for four macroeconomic regimes and different values of the Allen elasticities of substitution)

\begin{tabular}{lccc}
\hline & $\begin{array}{l}\text { Public } \\
\text { R\& D }\end{array}$ & $\begin{array}{l}\text { Public } \\
\text { education }\end{array}$ & $\begin{array}{l}\text { Private } \\
\text { R \& D }\end{array}$ \\
\hline Total employment & $0.0 / 0.1$ & 0.0 .0 .1 & $0.0 / 0.1$ \\
Production & $0.2 / 1.0$ & $-0.1 / 0.8$ & $0.1 / 0.7$ \\
Real after tax wage rate & $0.1 / 0.8$ & $0.3 / 0.8$ & $0.0 / 0.5$ \\
Stocks of & & & \\
- human capital & $0.0 / 1.6$ & $0.8 / 3.3$ & $0.0 / 0.4$ \\
- technology capital & $0.5 / 4.2$ & $-0.1 /-1.4$ & $3.1 / 5.2$ \\
- physical capital & $-1.7 / 0.3$ & $-2.6 /-0.1$ & $-0.3 / 0.3$ \\
\hline
\end{tabular}

Sources: Tables 4 and 5. 
simulations both with respect to the macroeconomic regime and the technology parameters allow us unambiguously to determine the signs of the reported effects in most cases. Admittedly, in the case of increased expenditures on public education we cannot determine the sign of the multiplier with respect to production, and likewise we find contradictory movements in the physical capital stock when R \& D expenditures (both public and private) change. In the other cases, however, we can determine the sign of the multipliers within the framework of the twofold sensitivity analysis of the MESEMET model. Indeed, in some cases we can state the likely impact of the proposed policy measures with some confidence. For example, independently of the proposed measure, the exact value of the Allen elasticities of substitution and the macroeconomic regime, we find that the three policy experiments all result in an increase in human capital which is reflected in a higher real after-tax wage rate.

The sensitivity analysis provides important insights with respect to the relevant parameters for the effectiveness of technology policies. In particular, the spillover effects from $R \& D$ on human capital seem to be crucial for the economic consequences of public $R \& D$ and tax-free allowances on private $R \& D$. Furthermore, the degree of complementarity between (physical and technology) capital and human capital is important for the degree in which public expenditures crowd out private investments in physical and technology capital. Indeed, a higher degree of complementarity raises the effectiveness of technology policies because it does not replace private activities but rather stimulates these investments.

Moreover, we refute the popular statement that technological progress endogenously reduces employment in a small open economy (den Butter and Wollmer, 1992). We do not find such a relationship, neither in the demand-driven disequilibrium version of the MESEMET model nor in the general equilibriumcum-supply side elements version and neither for low elasticities of substitution nor for high elasticities. In this sense our study contradicts the findings of earlier attempts to endogenize technological progress in a macroeconomic model for The Netherlands by den Butter and Wollmer (1992) and den Butter and van Zijp (1995).

\section{Appendix: MESEMET equations}

We use the linearized version of MESEMET, where all variables are denoted in rates of growth except in the equation for the budget deficit which is denoted as first differences as a fraction of GDP. Notation is explained at the end of the model.

Production capacity

$$
\begin{aligned}
& \dot{Y}_{p}=0.66 \dot{L}_{\text {eff }}+0.34 \dot{K}_{\text {eff }}, \\
& \dot{L}_{\text {eff }}=0.333 \dot{L}+0.667 \dot{H} c, \\
& \dot{K}_{\text {eff }}=0.85 K \dot{T}+0.15 \dot{K} g,
\end{aligned}
$$


$\dot{K g}=0.88 \dot{K_{g}}{ }_{-1}+0.12 \dot{I g}$,

$K \dot{T}=0.7 \dot{K p}+0.3 \dot{T} c$,

$\dot{T}_{c}=0.8 \dot{T} p+0.2 \dot{T} g$

$\dot{T} g=0.892 \dot{T}_{-1}+0.108 R \dot{D}_{g}$,

$\dot{H} c=0.88 \dot{H} c_{-1}+0.42 \dot{I} p+0.006 R \dot{D}_{\mathrm{p}}+0.018 R \dot{D}_{\mathrm{g}}+0.054 \dot{E g}-0.024 \dot{T}_{i}^{\prime}$,

$\dot{K}^{\mathrm{d}}=0.7 \dot{Y}^{\mathrm{d}}+2.8 \dot{K}_{\mathrm{cff}}-2.5 K \dot{T}-0.7 \dot{R}_{y}-0.1 \dot{T}_{k}^{\prime}$,

$\dot{K} p=0.88 \dot{K K}_{-1}+0.12 \dot{I p}$,

$\dot{I} p^{\mathrm{d}}=0.1 \cdot\left(8.333 \cdot\left(\dot{K}^{\mathrm{d}}-\dot{K} p_{-1}\right)\right)+\dot{K}_{-1}$,

$\dot{T}^{\mathrm{d}}=0.5 \dot{Y}^{\mathrm{d}}+2 \dot{K}_{\mathrm{cff}}-1.786 K \dot{T}+0.286 \dot{T} c-0.5 \dot{P}_{\mathrm{rd}, y}-0.1 \dot{T}_{k}^{\prime}$,

$\dot{T}_{p}=0.892 \dot{T p}_{-1}+0.108 R \dot{D}_{\mathrm{p}}$,

$R \dot{D}_{\mathrm{p}}^{\mathrm{d}}=0.05 \cdot\left(9.259 \cdot\left(\dot{T} p^{\mathrm{d}}-\dot{T}_{p_{-1}}\right)\right)+\dot{T}_{p_{-1}}$.

Labour market

$$
\begin{aligned}
& \dot{L}^{\mathrm{d}}=0.55 \dot{Y}^{\mathrm{d}}+0.45 L_{\mathrm{eff}}-0.55 W_{y}, \\
& L \dot{r} d=R \dot{D}_{\mathrm{p}}, \\
& \dot{L}_{\mathrm{p}}=0.99 \dot{L}+0.01 L \dot{r} d, \\
& \dot{L}=0.9 \dot{L}^{\mathrm{d}}+0.1(1.159 \dot{L} s-0.149 \dot{L} g-0.01 L \dot{r} d), \\
& \dot{L}_{\mathrm{tot}}=0.871 \dot{L} p+0.129 \dot{L} g, \\
& \dot{L} s=1.254 \dot{L} s_{\mathrm{au}}+0.15 \dot{W}_{n}^{\prime}-0.254 Y \dot{u} o-0.25 \dot{L} u, \\
& \Delta \dot{P}_{l}=\Delta \dot{P}+\Delta \dot{H}+0.25 \Delta \dot{T}_{l}-0.25 \dot{L} u, \\
& \dot{H}=\dot{Y}-\dot{L} p .
\end{aligned}
$$

Capital market

$$
\begin{aligned}
& \dot{Y}_{r_{\mathrm{n}}}=\dot{Y} r-0.5 \dot{T}_{k}^{*}, \\
& \Delta \dot{P}_{k}=\Delta \dot{R}+3\left(\dot{S} r-\dot{Y}_{\mathrm{n}}\right), \\
& \dot{S} r=1.433 \dot{I} p+0.067 \text { Ird }-11.111 \Delta \frac{K R r}{Y_{\mathrm{tot}}},
\end{aligned}
$$




$$
\begin{aligned}
& \dot{R}=\dot{R}_{\mathrm{f}}, \\
& \dot{R}_{\mathrm{rrn}}=\dot{R}_{\mathrm{rn}}-\dot{P}, \\
& \dot{R}_{y}=\dot{P}_{k}-\dot{P}_{y}, \\
& \Delta \frac{K R r}{Y_{\mathrm{tot}}}=\Delta \dot{R}_{\mathrm{rrn}}-\Delta \dot{R}_{\mathrm{rf}} .
\end{aligned}
$$

\section{Real expenditure}

$$
\begin{aligned}
& \dot{X}=0.7 \dot{C}+0.143 \dot{I}_{\mathrm{p}}+0.007 R \dot{D}_{\mathrm{p}}+0.1 \dot{G}+0.05 \dot{I}_{\mathrm{g}}, \\
& \dot{C}^{\mathrm{d}}=0.476\left(\dot{L} p+\dot{W}_{\mathrm{n}}\right)+0.079\left(\dot{L} g+\dot{W}_{\mathrm{n}}\right)+0.341 \dot{Y}_{u}+0.103 \dot{Y}_{\mathrm{n}}, \\
& \dot{C}=0.2\left(\dot{C}^{\mathrm{d}}+\dot{C}_{-1}^{\mathrm{d}}+\dot{C}_{-2}^{\mathrm{d}}+\dot{C}_{-3}^{\mathrm{d}}+\dot{C}_{-4}^{\mathrm{d}}\right), \\
& \dot{Y}=\dot{X}+0.65(\dot{B}-\dot{M}), \\
& \dot{Y}^{\mathrm{d}}=0.4 \dot{Y}+0.3 \dot{Y}_{-1}+0.2 \dot{Y}_{-2}+0.1 \dot{Y}_{-3} \\
& \dot{Y}_{\mathrm{tot}}=0.9 \dot{Y}+0.1 \dot{Y} g \\
& \dot{I p}=\dot{I}^{\mathrm{d}}, \\
& R \dot{D} p=R \dot{D}_{\mathrm{p}}^{\mathrm{d}}, \\
& l i d=R \dot{D}_{\mathrm{p}}, \\
& \dot{Y} r=3\left(\dot{Y}+\dot{P}_{y}\right)-2\left(\dot{L} p+\dot{P}_{l}\right)-\dot{P}+0.04 \cdot R \dot{D}_{\mathrm{sub}} \cdot\left(1+0.01 R \dot{D}_{\mathrm{p}}\right) .
\end{aligned}
$$

\section{Incomes and prices}

$$
\begin{aligned}
& \dot{W}=\dot{P}_{l}-\dot{P}, \\
& \dot{W}_{y}=\dot{P}_{l}-\dot{P}_{y}, \\
& \dot{W}_{\mathrm{n}}=\dot{W}-\dot{T}_{l}, \\
& \dot{W}_{\mathrm{n}}^{\prime}=\dot{W}-1.564 \dot{T}_{i}, \\
& \dot{W}_{g}=\dot{W}, \\
& \dot{W}_{\mathrm{n}}=\dot{W}_{\mathrm{n}}+\dot{W}_{\mathrm{au}} \\
& \dot{P}_{y}=1.65 \dot{P}-0.65 \dot{P}_{\mathrm{f}}, \\
& \dot{P}_{\mathrm{rd}, y}=0.5 \dot{W_{y}}+0.5 \dot{R}_{y}-R \dot{D}_{\mathrm{sub}} .
\end{aligned}
$$

\section{Government}

$$
\dot{L} g=0.6 \dot{L} g_{\mathrm{au}}+0.3 \dot{E} g+0.1 R \dot{D}_{\mathrm{g}},
$$




$$
\begin{aligned}
& \dot{Y} g=\dot{L} g+\dot{W} g \\
& \dot{Y} g_{\mathrm{n}}=\dot{L} g+\dot{W} g_{\mathrm{n}}, \\
& \dot{T}_{l}=\dot{T}_{l}^{\prime}+0.4 \dot{W}, \\
& \dot{T}_{\mathrm{u}}=\dot{T}_{\mathrm{u}}^{\prime}+0.4 \dot{W}, \\
& \dot{T}_{i}=0.82 \dot{T}_{l}+0.18 \dot{T}_{\mathrm{u}} \\
& \dot{T}_{i}^{\prime}=0.82 \dot{T}_{l}^{\prime}+0.18 \dot{T}_{\mathrm{u}}^{\prime}, \\
& \dot{T} n=0.75\left(\dot{L} p+\dot{W}+\dot{T}_{l}\right)+0.25\left(\dot{Y} r+\dot{T}_{k}^{\prime}\right) \\
& \dot{U} g_{\mathrm{n}}=0.438 \dot{Y} u_{\text {ia }}+0.225 \dot{G}+0.113 \dot{I g}+0.125 Y g_{\mathrm{n}}+0.1\left(\dot{L} u+\dot{W}_{\mathrm{n}}\right) \\
& +0.03 \cdot R \dot{D}_{\text {sub }} \cdot\left(1+0.01 R \dot{D}_{\mathrm{p}}\right) \\
& \Delta \frac{F}{Y_{\text {tot }}}=0.4(\dot{T} n-U \dot{g} n), \\
& \dot{Y}_{u}=0.814 \dot{Y}_{u} \text { ia }+0.186\left(\dot{L} u+\dot{W}_{\mathrm{n}}\right) \text {, } \\
& \dot{Y}_{u_{\mathrm{ia}}}=1.49 \text { Yüo }-0.49\left(\dot{L} s+\dot{W}_{\mathrm{n}}\right) \text {. }
\end{aligned}
$$

External position

$$
\begin{aligned}
& \dot{B}=\dot{M}_{\mathrm{w}}+2 \dot{E} R+0.6 R \dot{I C}+0.4 R \dot{H} C, \\
& \dot{M}=\dot{Y}-0.75 \dot{E} R \\
& \dot{E} R=\dot{P}_{\mathrm{f}}-\dot{P} \\
& R \dot{I C}=\dot{T}_{C}-\dot{T} c_{\mathrm{f}},
\end{aligned}
$$

$$
R \dot{H C}=\dot{H} c-\dot{H} c_{f} .
$$

\section{Endogenous variables}

$$
\begin{array}{ll}
B & =\text { real exports of goods and services } \\
C & =\text { real private consumption } \\
C^{\mathrm{d}} & =\text { desired level of real private consumption } \\
E R & =\text { price level of foreign goods relative to domestic goods } \\
F & =\text { government budget deficit } \\
H & =\text { labour productivity } \\
H c & =\text { domestic stock of human capital } \\
I p & =\text { gross private investment (excluding } \mathrm{R} \& \mathrm{D} \text { related expenditures) } \\
I p & =\text { desired gross private investment (excluding } \mathrm{R} \& \mathrm{D} \text { related expenditures) } \\
I r d & =\text { physical private investment related to } \mathrm{R} \& \mathrm{D} \\
K_{\mathrm{cff}} & =\text { effective capital input } \\
K g & =\text { public capital stock }
\end{array}
$$


$K p \quad=$ private (physical) capital stock

$K p^{\mathrm{d}} \quad=$ desired private capital stock

$K R r=$ net import of physical capital

$K T=$ composite input of private capital stock and technology capital

$L \quad=$ private employment (excluding researchers)

$L^{\mathrm{d}} \quad=$ labour demand (excluding researchers)

$L_{\text {eff }} \quad=$ effective labour input

$L g \quad=$ public sector employment

$L p \quad=$ total private employment (including researchers)

Lrd $=$ employment in private sector $\mathrm{R} \& \mathrm{D}$ departments

$L s \quad=$ labour supply

$L_{\text {tot }}=$ total employment

$L u \quad=$ unemployment

$M \quad=$ imports of goods and services

$P \quad=$ consumer price of goods and services

$P_{k} \quad=$ nominal pre-tax return on domestic investment

$P_{l} \quad=$ nominal before-tax private sector wage rate

$P_{\mathrm{rd}, \mathrm{p}}=$ real costs of private $\mathrm{R} \& \mathrm{D}$ activities

$P_{\mathrm{y}} \quad=$ production price

$R \quad=$ long term before tax interest rate

$R D_{\mathrm{p}} \quad=$ private $\mathrm{R} \& \mathrm{D}$ activities

$R D_{\mathrm{p}}^{\mathrm{d}}=$ desired private $\mathrm{R} \& \mathrm{D}$ activities

$R H C=$ relative human capacity

$R I C=$ relative innovation capacity

$R_{\text {rrn }}=$ real after tax return on domestic investment

$R_{y} \quad=$ real capital cost

$S r \quad=$ supply of physical capital

$T \quad=$ total tax revenue

$T c \quad=$ domestic stock of technology (or R \& D) capital

$\mathrm{Tg} \quad=$ stock of publically available technological knowledge

$T_{i} \quad=$ average integrated tax rate on labour income

$T_{i}^{\prime} \quad=$ marginal integrated tax rate on labour income

$T_{l} \quad=$ average tax rate on labour income

$T p \quad=$ private stock of technological knowledge

$T p^{\mathrm{d}}=$ desired private stock of technological knowledge

$T u=$ average cut in transfers due to an income rise of $1 \%$

$U g \quad=$ gross government outlays

$W \quad=$ real before-tax private sector wage rate

$W_{\mathrm{n}} \quad=$ real after tax private sector wage rate

$W_{\mathrm{n}}^{\prime} \quad=$ real effective private sector wage rate (taking into account both taxes and transfers)

$W g \quad=$ real before tax public sector wage rate

$W g_{\text {n }} \quad=$ real after tax public sector wage rate

$W_{\mathrm{y}} \quad=$ real labour cost in private sector

$X=$ domestic expenditure

$Y \quad=$ actual private production

$Y_{p} \quad=$ private production capacity

$Y^{\mathrm{d}} \quad=$ desired private sector production capacity

$\mathrm{Yg}=$ before tax public sector wages 


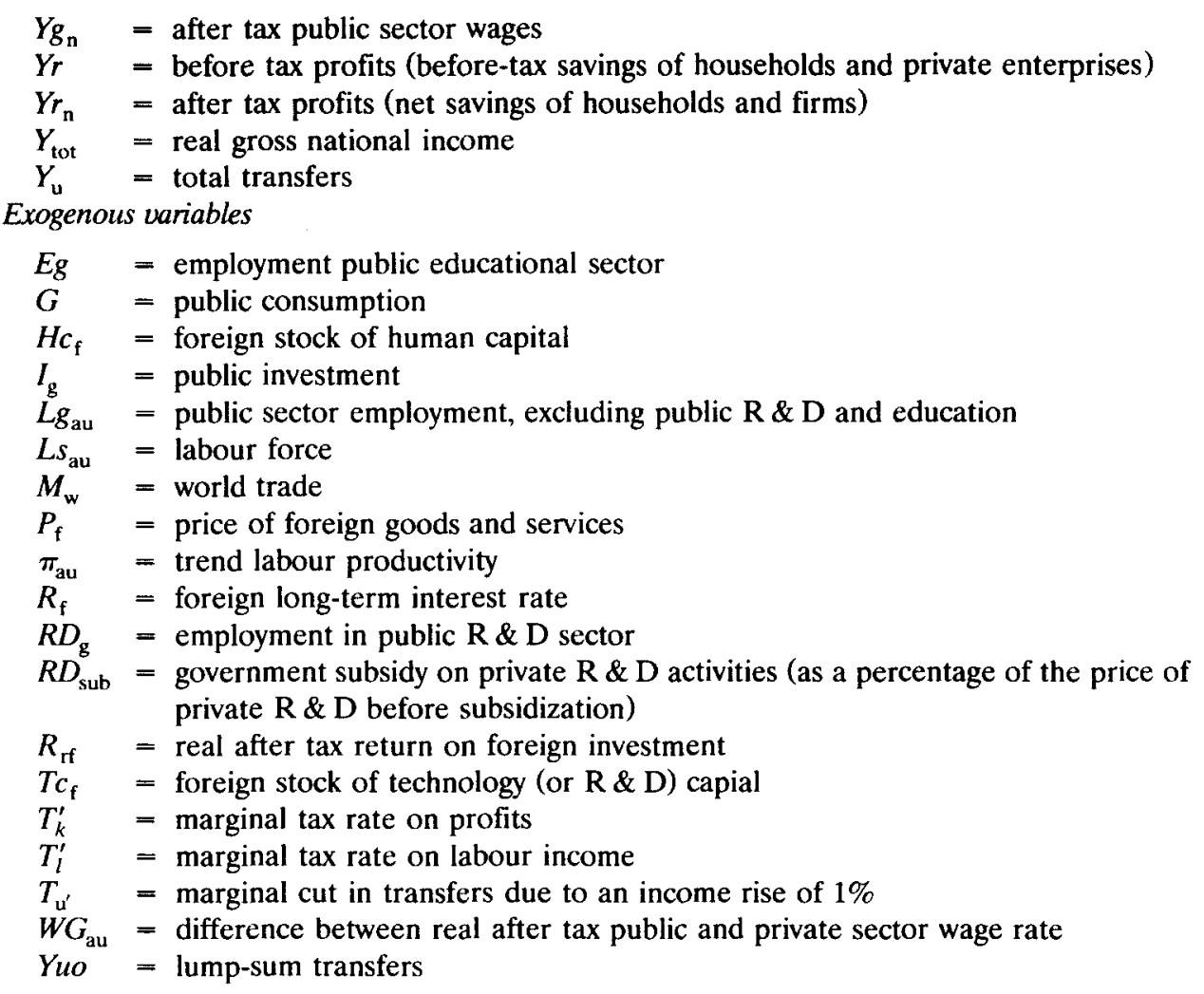

\section{Acknowledgements}

Comments by Lans Bovenberg, Frank den Butter, Mathijs van Dijk, Robert Haffner, Pieter Waasdorp and Rudy van Zijp are gratefully acknowledged. This paper does not necessarily reflect the opinion of the Government of The Netherlands. Gilbert van Hagen would like to thank The Netherlands Organization for Scientific Research (NWO) for financial support.

\section{References}

Barro, R.J. and X. Sala-i-Martin, 1992, Convergence, Journal of Political Economy 100, 223-251.

Benhabib, J. and B. Jovanovich, 1991, Externalities and growth accounting, American Economic Review $81,82-113$.

Bergeijk, P.A.G. van and R.C.G. Haffner, 1996, Deregulation, privatization and the macroeconomy: measurement, modelling and policy. (Edward Elgar; Cheltenham).

Bergeijk, P.A.G. van, R.C.G. Haffner and P.M. Waasdorp, 1993, Measuring the speed of the invisible hand: The macroeconomic costs of price rigidity, Kyklos 46, No. 4, 529-544.

Blinder A. and Y. Weiss, 1976, Human capital and labor supply: A synthesis, Journal of Political Economy 84, 449-472.

Brakman, S., 1991, International trade modelling: Decomposition analyses, Wolters Noordhoff, Groningen. 
Broer, D.P. and W.J. Jansen, 1989, Employment, schooling and productivity growth, De Economist 137, No. 4, 425-453.

Brouwer, E. and A. Kleinknecht, 1993, Technologie en de Nederlandse concurrentiepositie: een onderzoek op micro-en meso-niveau (Technology and Dutch competitiveness: A micro- and mesoeconomic survey. Beleidsstudies Technologie/Economie 23, Ministry of Economic Affairs, The Netherlands (In Dutch).

Butter, F.A.G. den and F.J. Wollmer, 1992, Endogenizing technical progress in The Netherlands, Beleidsstudies Technologie/Economie 22, Ministerie van Economische Zaken, Den Haag.

Butter, F.A.G. den and R. van Zijp, 1995, Technologie en werkgelegenheid (Technology and employment), Beleidsstudies Technologie/Economie 29, Ministerie van Economische Zaken, Den Haag (In Dutch).

Davies, J. and J. Whalley, 1989, Taxes and capital formation. How important is human capital? NBER Working Paper 2899.

Evangelista, R, 1994, Embodied and disembodied innovative activities: Evidence from the Italian innovation survey, Paper for the Fifth Conference of the International Joseph A. Schumpeter Society, Münster.

Fagerberg, J. 1994, Is there a small-country disadvantage in high-tech? Paper for the Fifth Conference of the International Joseph A. Schumpeter Society, Münster.

Griliches, Z., 1979, Issues in assessing the contribution of research and development to productivity growth, Bell Journal of Economics 10, 92-116.

Haffner, R.C.G. and P.A.G. van Bergeijk, 1994, The economic consequences of Dutch politics, De Economist 142, No. 4, 497-505.

Hagen, G.H.A. van, R.C.G. Haffner and P.M. Waasdorp, 1995, How strong is the case for public investments in human capital? Assessments with an AGE model, Paper 51 st IIPF Congress, Lisbon, 21-24 August.

Hebbink, G.E., 1991, Employment by level of education and production factor substitutability, De Economist 139, No. 3, 379-400.

Hulst, N. van, and L.L.G. Soete, 1989, Export en technologische ontwikkeling in de industrie (Exports and technological development in manufacturing), in: Export, Preadviezen van de Koninklijke Vereniging voor Staatshuishoudkrunde, Stenfert Kroese, Leiden, blz. 63-85 (In Dutch).

Maddison, A., 1995, Monitoring the world-economy 1820-1922 (OECD; Paris).

Magnier, A. and J. Toujas-Bernate, 1994, Technology and trade: Empirical evidences for the major five industrialized countries, Weltwirtschaftliches Archiv 138, No. 3, 494-520.

Mankiw, N.G., D. Romer and D.N. Weil, 1992, A contribution to the empirics of economic growth, The Quarterly Journal of Economics, 407-437.

Miller, R., 1994, Investment knowledge and knowledge investment: The need to rethink human capital information and decision making systems, mimeo, (OECD; Paris).

Ministry of Economic Affairs, 1995a, Calibratie MEOM-Basisjaar 1992, Research memorandum 9501, The Hague.

Ministry of Economic Affairs, 1995b, Economic policy, technology and growth, Research memorandum 9502, The Hague.

Perroni, C., 1995, Assessing the dynamic efficiency gains of tax reform when human capital is endogenous, International Economic review 36, 907-925.

Rebelo, S., 1991, Long-run policy analysis and long-run growth, Journal of Political Economy 99, No. 3, 500-521.

Reininga, T., 1994, De relatieve factorintensiteit van de Nederlandse export (Relative factor intensity of Dutch exports), ESB 79, No. 3979, 898-940 (In Dutch).

Romer, P.M., 1986, Increasing returns and long run growth, Journal of Political Economy 94, No. 5, $1002-1037$.

Sala-i-Martin, X., 1990a, Lecture notes on economic growth (I): Introduction to the literature and neoclassical models, NBER Working Paper no. 3563.

Sala-i-Martin, X., 1990b, Lecture notes on economic growth (II): Five prototype models of endogenous growth, NBER Working Paper no. 3564. 
Schultz, T.W., 1961, Investment in human capital, American Economic Review 51, 1-17.

Shah, A., 1994, The economics of research and development: How research and development capital affects production and markets and is affected by tax incentives, Policy Research Working Paper 1325 , The World Bank, Washington.

Sinderen, J. van, 1990, Belastingheffing en economische groei (Taxation and economic growth) (Wolters Noordhoff; Groningen).

Sinderen, J. van, 1993, Taxation and economic growth, Economic Modelling 13, 285-300.

Trostel, P.A., 1993, The effect of taxation on human capital, Journal of Political Economy 101, No. 2, 327-350. 